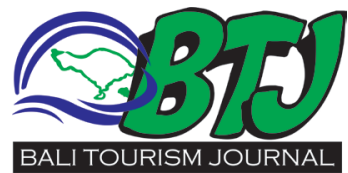

\title{
Minister Terawan encourages Usadha Bali development under Traditional Balinese Medicine branding
}

\author{
IB Gede Karyambara Putra
}

\section{ABSTRACT}

In Bali, Study of traditional herbal medicine is known under term Usadha, derived from Sanskrit word Ausadhi means healing plants. The ancient wisdom of botanical medicine texts has been compiled on Lontar (Dried-Borassus leaf) under name Lontar Usadha. Traditional Balinese Usadha treatment is carried out by a shaman called Balian; whether Balian Ketakson or Balian Usadha. Usadha practice on the island of Bali is strongly related to herbal plants' existence. Herbal medication has been proven in Bali as a primary treatment for the patient since ancient times. However, due to current medication service, people no longer prefer a botanical-based therapy as the first option. As a result, the number of herbal plants on the island of Bali has been plummeting over the years. Although on some occasions, the central government and provincial government had suggested cultivating herbaceous plant as a decorative plant on a household level, yet the program did not make any significant impact. In December 2019, Governor of Bali, Wayan Koster expressed his deep interest on indigenous health service industry to be provided by hospitals, both state and private. On occasion, Indonesia minister of Health, Terawan Agus Putranto, showed his support for the development of health tourism, travelling medicine, and complementary traditional services with local genius. They both agreed that the service would be promoted under 'Traditional Balinese Medicine (TBM) service' branding. In future, it is expected that TBM would be available as an alternative service on Bali hospitals. The facility would promote herbal industry development as well as herbal plant preservation through the availability of local herb farms to be established in Bangli, Karangasem, and Tabanan areas.

Keyword: Usadha, Indigenous Herbal Medicine, Minister of Health, Traditional Balinese Medicine

Cite This Article: Putra, I.B.G.K. Minister Terawan encourages Usadha Bali development under Traditional Balinese Medicine branding. Bali Tourism Journal (BTJ) 2020, 4(1): 10-13. D0I : 10.36675/btj.v4i1.40

${ }^{1}$ AVSEC PT. Angkasa Pura; colekpamor9@gmail.com

Editor:

Ida Bagus Ngurah Tri Pramana
Received : 2020-02-04 Accepted : 2020-02-28 Published: 2020-03-16

\section{BACKGROUND}

Indonesia Minister of Health, Lt. Gen. (ret.) Dr Terawan Agus Putranto Sp. Rad (K) RI interested in Usadha to be provided by Bali hospitals. ${ }^{1}$ In Bali, Study of traditional herbal medicine is known under term Usadha, derived from Sanskrit word Ausadhi means healing plants. ${ }^{2}$ It is believed the knowledge has been passed along as part of Hinduism teaching, compiled in Veda known as Ayurveda. Blessed with tropical climate across equator provides Bali with vast green vegetation. Throughout history, it has been a source of food as well as medicine for the indigenous people. The method of using plants as a source of medicine has been well known on the island of Bali since the $5^{\text {th }}$ century. A practice in utilising plant or tree as a remedy is known as herbal medicine. According to WHO, herbal medicine is acknowledged and preferred by the most population who resides in Asian and African continents. ${ }^{3}$ The ancient civilisation through experiences has attained an excellent knowledge to process plant or tree into healing agent; start from its root, stem, bark, leave, fruit, sap or even fungus and parasite.

\section{INDIGENOUS HERBAL MEDICINE}

The ancient wisdom of botanical medicine texts has been compiled on Lontar (Dried-Borassus leaf) under term Lontar Usadha. ${ }^{4}$ On the island of Bali; the community have been considering the Lontar as a sacred text. Its content was a legacy from their ancestor; thus, the people respect the knowledge as they recognise their late predecessor. As for the lontar usadha, the text helps to identify the source of the disease, which can be caused by Sekala (physical) or Niskala (magical) disease. ${ }^{5}$ Traditional Balinese Usadha treatment is carried out by a shaman called Balian; whether Balian Ketakson or Balian Usadha. Balian Ketakson is a shaman that gets its expertise through mythical power that possessed the practitioner, and the power influences the shaman's thought, speaking and behaviour. While Balian usadha is a shaman that obtain the knowledge through study the science of medicine, either from a teacher or self-learning. Besides to have a profound understanding on the herbs, Balian is mandatory to learn some related texts regarding traditional medical science in diagnosing the source of diseases such as Lontar Ratu ning Usadha, Tutur Buda Kecapi, Sastra Sanga and Genta pinara pitu. ${ }^{6}$ 


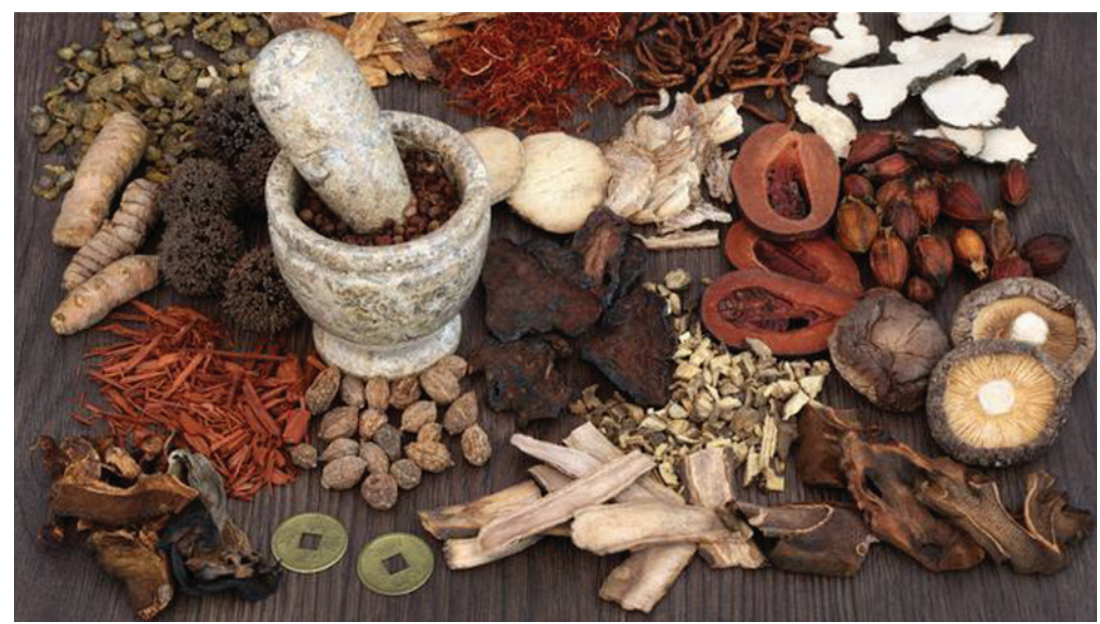

Figure 1. Blessed with tropical climate across equator provides Bali with vast green vegetation. Throughout history, it becomes a source of food as well as medicine for the indigenous people. ${ }^{7}$

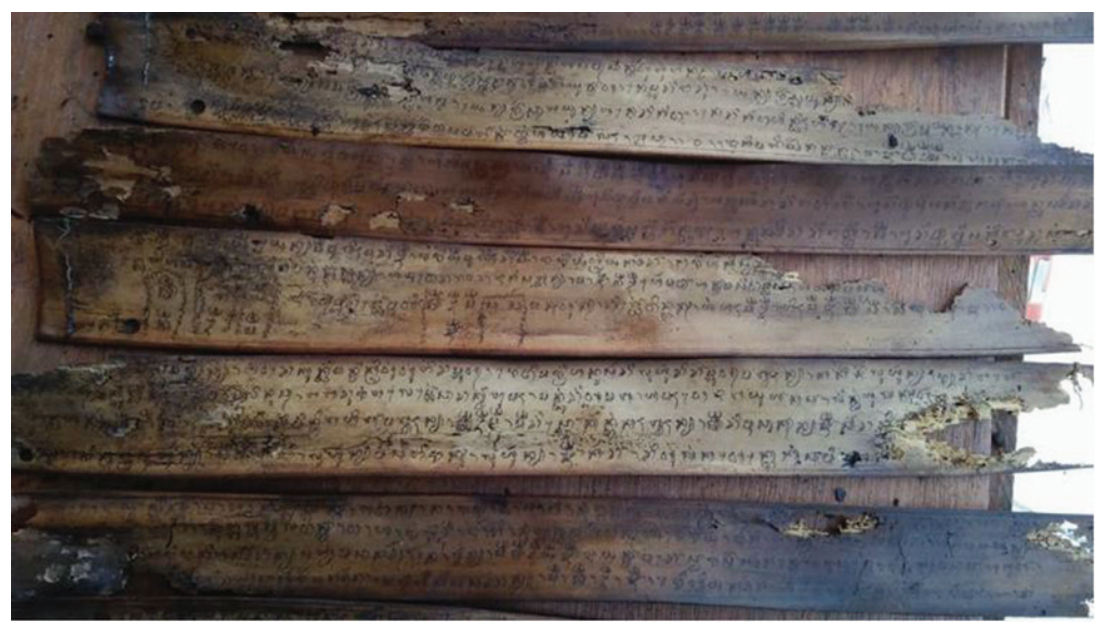

Figure 2. On the island of Bali, the community, have been considering the Lontar as a sacred text. Its content was a legacy from their ancestor; thus the people respect the knowledge as they recognise their late predecessor $^{10}$

Some famous titles of Lontar usadha such as Ratu ning Usadha, Usadha Taru premana, Usadha buduh, Usadha Rare, Usadha Kacacar, Usadha Tuju, Usadha Paneseb, Usadha Dalem, Usadha Ila, Usadha Bebai, Usadha Ceraken Tingkeb, Usadha Tiwang, Usadha Darmosada, Usadha Uda, Usadha Indrani, Usadha Kalimosada, Usadha Kamarus, Usadha Kuranta Bolong, Usadha Mala, Usadha Rukmini Tatwa, Usadha Smaratura, Usadha Upas, Usadha Yeh, Usadha Buda Kecapi, Usadha Cukil Daki, Usadha Kuda, Usadha Pamugpug, and Usadha Pamugpugan. ${ }^{8}$ Each lontar mentions various type of diseases as well as suggests the suitable herb to heal it.

There were a few times in the history of Bali where plagues and diseases take their tolls. Usadha knowledge has been a solution to stop the outbreak. Indigenous society was firmly believed to mystical power. It is shown from the fact that no one could provide an exact answer regarding how folk research their way to identify such a specific herb for a particular disease. The knowledge is shrouded in mystery with a robust mythical foundation. From the written history, it is believed that the study had been passed from God or deities as compassion to humankind. For instance, in lontar usadha Taru Pramana, although the text was written by Mpu Kuturan, yet the author claimed that he was taught the knowledge by Goddess Durga in his meditation. ${ }^{9}$

From many lontar usadha, lontar usadha Taru pramana is considered popular amongst Balinese to hitherto. Up to recent finding, the text encompasses the most type of vegetation that any lontar usadha ever mentioned. The script explained that there are approximately more than 150 types of plant that can be utilised as medicine. A study by Arsana (2019), identified that on Lontar Taru Pramana, the plants from the family of Euphorbiaceae, Moraceae, Fabaceae, and Zingiberaceae are dominant.

Bijekar and Gayatri (2014), as cited by Arsana (2019), explained that Euphorbiaceae covers more than 300 genus and 8000 species. This plant type benefits to ease inflammation, asthma, hypoglycaemic, and diabetes due to its antibacterial and antioxidant agent. Moraceae, according to Zerega $(2005 ; 2010)$ and Clement \& Weiblen (2009), covers 37 genus and 1000 species that can be easily obtained around the tropical area. Fabaceae, as suggested by Danarto (2013), has 630 genus and 18.000 species with high economic value while the Zingiberaceae family is accessible and commonly used by the community as spices.

Besides mentioning what plant to use in healing specific disease, usadha texts stated several methods in applying the herb to the patient. Parts of the tree may be squeezed or ground to extract the juice (loloh) to be drunk by the patient. It can be pulverised and mixed with water, vinegar or arak, then smeared on the body as boreh or on a specific area as tampel. Then, there is a method where the herb may be chewed and sprayed through the mouth (simbuh). Tutuh is a drop medicine, that is obtained from the herb's essence. Ses, a method to boil ingredients. Once its temperature goes down, the liquid is incorporated as a cleansing solution on wound or bruise, and many other unnamed procedures. Sometimes, other ingredients such as salt, coconut oil, water, vinegar, alcohol and lime betel are added to the herb's mixture. ${ }^{5}$ 


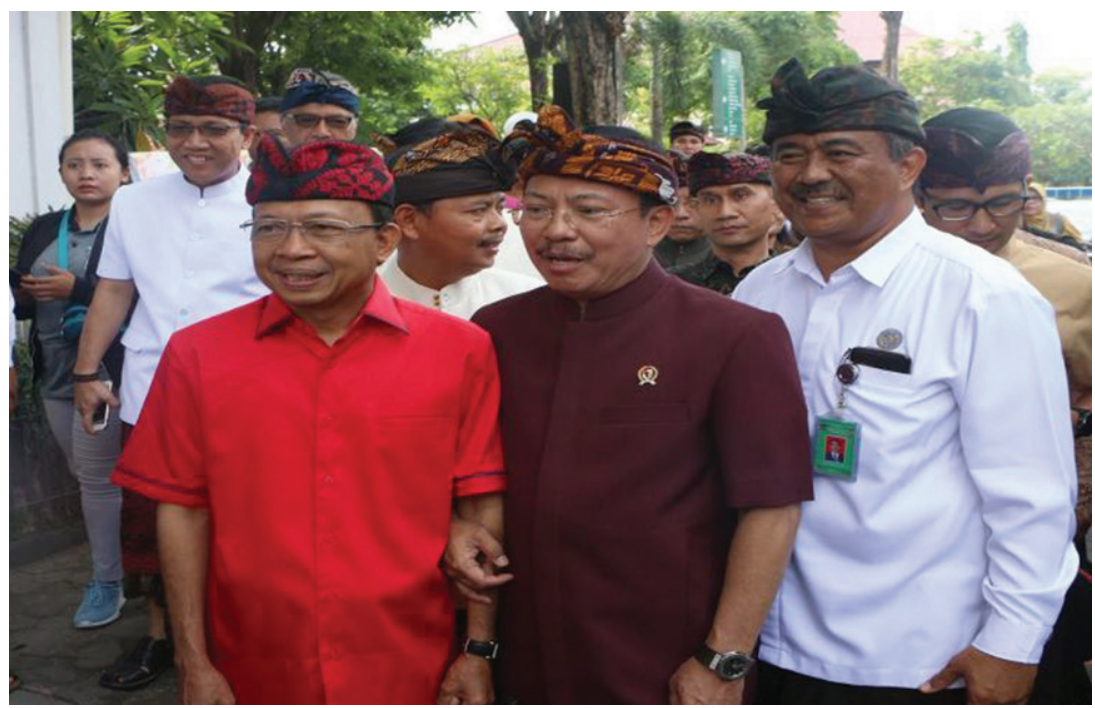

Figure 3. On Purple uniform, Indonesia Minister of Health, Lt. Gen. (ret.) Dr Terawan Agus Putranto SpRad (K) RI, together with Governor of Bali, Dr I Wayan Koster on red uniform ${ }^{13}$

\section{THE HERBAL PLANTS' EXISTENCE}

Today, herbal medicine is not as popular as it used to since pharmaceutical medication becomes more appreciated in society. The situation leads to a decreasing number of herbaceous plants on its habitat due to low society awareness. Modern Balinese is unaware of the situation since they no longer solely rely on herbal type medication. A study by Sutomo and Iryadi (2019) revealed there were 332 types or approximately $67 \%$ of 491 herbaceous plants that catalogued on Lontar Usadha Bali have been preserved on Bali Botanical Garden. ${ }^{2}$ While the rest of the plant, whether it is nearly extinct or no longer grows on Bali island. Further study suggests it is estimated that around 90 to $95 \%$ of raw pharmaceutical materials (ethical drugs) have been imported from authorised suppliers by 225 companies in Indonesia. It results in skyrocketing medicine price. Since 2000, it has been giving a significant impact on the cost of health service. Therefore, health becomes such a luxury. ${ }^{11}$

Up to the moment, the Bali community's concern for medicinal plants has not a priority. Albeit, few efforts have been conducted such as green planting around Ubud \& Tampaksiring, Gianyar regency and Karangasem regency with a foreign-owner majority. Planting the herb at household level was a Government program before 2010, however until now, its existence is small and limited. Thus, it does not give a significant effect on herb existence. It is expected that the idea to establish herb farm can be proportionately responded by the wider local community. ${ }^{12}$

\section{BRANDING OF TRADITIONAL BALINESE MEDICINE}

On December 2019, Indonesia Minister of Health, Lt. Gen. (ret.) Dr Terawan Agus Putranto SpRad (K) RI, together with Governor of Bali, Dr I Wayan Koster, inaugurated the traditional and complementary polyclinic of Sanglah Central General Hospital (RSUP), Denpasar City, Bali. On occasion, Wayan Koster announced Bali Governor Regulation Number 55/2019 concerning Traditional Balinese Health Services has been active, to open traditional health services in both Bali state and private hospitals. He referred to the fact that Bali has a wide variety of unnoticed literary references and lontar about herbal medicine. With proper management, It can be used as a reference for medical service based on local wisdom. Minister of Health, Terawan Agus Putranto supports the development of traditional health services based on local knowledge, subsequently to encourage the development of health tourism, travelling medicine, and complementary traditional services with local genius. He and the Governor of Bali would also launch a branding of 'Traditional Balinese Medicine (TBM) service' in every hospital in Bali. Starting from Bali as a pilot project, then adapted by other provinces in Indonesia. ${ }^{1}$

As a follow-up activity, In February 2020, as series of Balinese Language Month festival, Provincial Government of Bali exhibited a mass traditional healing service. The event was a strategic event of the Provincial Government to raise the community's interest in indigenous herbal medication that sourced from Lontar Usadha. ${ }^{14}$ In future, traditional Balinese health service would be handled under standardised herbal industry. It is expected that the industry would produce standardised herbs; thus, it can be marketed on a broader scale. Furthermore, to support the herb farm, Bangli, Karangasem, and Tabanan areas have been chosen as a suitable location to cultivate the medical plants.

\section{CONCLUSION}

Usadha practice on the island of Bali is strongly related to herbal plants' existence. Herbal medication has been proven in Bali as a primary treatment for the patient since ancient times. However, due to current medication service, people no longer prefer a botanical-based therapy as the first option. As a result, the number of herbal plants on the island of Bali has been plummeting over the years. Although on some occasions, the central government and provincial government had suggested cultivating herbaceous plant as 
a decorative plant on a household level, yet the program did not make any significant impact. In December 2019, Governor of Bali, Wayan Koster expressed his deep interest on indigenous health service industry to be provided by hospitals, both state and private. On occasion, Indonesia minister of Health, Terawan Agus Putranto, showed his support for the development of health tourism, travelling medicine, and complementary traditional services with local genius. They both agreed that the service would be promoted under 'Traditional Balinese Medicine (TBM) service' branding. In future, it is expected that TBM would be available as an alternative service on Bali hospitals. The facility would promote herbal industry development as well as herbal plant preservation through the availability of local herb farms to be established in Bangli, Karangasem, and Tabanan areas.

\section{REFERENCES:}

1. AAG Agung. RSUP Bali Miliki Layanan Kesehatan Tradisional. Gatra. 2019. Available at URL: https://www. gatra.com/detail/news/464058/kesehatan/rsup-bali-milikilayanan-kesehatan-tradisional

2. Sutomo S, Iryadi R. Konservasi Tumbuhan Obat Tradisional "Usada Bali". Buletin Udayana Mengabdi. 2019;18(4)

3. WORLD HEALTH ORGANISATION, et al. General guidelines for methodologies on research and evaluation of traditional medicine. World Health Organization, 2000.

4. IK Suwidja. Berbagai Cara Pengobatan Menurut Lontar Usada Pengobatan Tradisonal Bali. Indra Jaya - Singaraja. 1989.

5. IN Arsana. Keragaman Tanaman Obat dalam Lontar "Taru Pramana" dan Pemanfaatannya untuk Pengobatan Tradisional Bali. Jurnal Kajian Bali (Journal of Bali Studies), 2019, 9.1: 241-262.
6. D Saraswati. Ratu Ning Usadha, Lontar Cara Mendiagnosa Penyakit. Bali Express. 2018. Available at URL: https:// baliexpress.jawapos.com/read/2018/03/27/60266/ratuning-usadha-lontar-cara-mendiagnosa-penyakit

7. Image from A Yuda 'Konsumsi 4 Tanaman Herbal Ini Untuk Perkuat Imunitas Tubuh Hindari Virus Corona Covid-19' Liputan6[dot]com. 2020. Available at URL: https://www.liputan6.com/bola/read/4220364/konsumsi4-tanaman-herbal-ini-untuk-perkuat-imunitas-tubuhhindari-virus-corona-covid-19\#

8. S Lanus. 'Apakah Bali Kebal Wabah Covid-19?'. Tatkala. 2020. Available at URL: https://tatkala.co/2020/03/21/ apakah-bali-kebal-wabah-covid-19/

9. Anonim. Taru Premana. Dinas Kesehatan Prop - DATI I Bali. 1979.

10. Image from desa sedang website 'Lontar Bali, Tradisi dan Warisan Leluhur Masyarakat Bali'. badungkab[dot]go[dot] id. 2018. Available at URL: http://desasedang.badungkab. go.id/baca-berita/2276/Lontar-Bali--Tradisi-dan-WarisanLeluhur-Masyarakat-Bali.html

11. DHOMIRI, A. Semerbaknya obat tradisional di tengah krisis. Majalah Teknologi, 2000, 158: 6-10.

12. Adiputra, N., Aman, I.G.M., Manuaba, I.B.P. The toxicity of antiviral plants used in Balinese traditional medicine. Bali Medical Journal 6 (2):243-246. 2017. DOI:10.15562/bmj. v6i2.537.

13. Image from Beritabali 'Gubernur Koster Siapkan Layanan Kesehatan Terintegrasi Berbasis Online’. Beritabali. 2019. Available at URL: https://www.news.beritabali.com/ $\mathrm{read} / 2019 / 07 / 08 / 201912310001 /$ gubernur-koster-siapkanlayanan-kesehatan-terintegrasi-berbasis-online

14. Novi. Layanan Pengobatan Tradisional Warnai 'Bulan Bahasa Bali 2020’. Nusa Bali. 2020. Available at URL: https:// www.nusabali.com/berita/68667/layanan-pengobatantradisional-warnai-bulan-bahasa-bali-2020

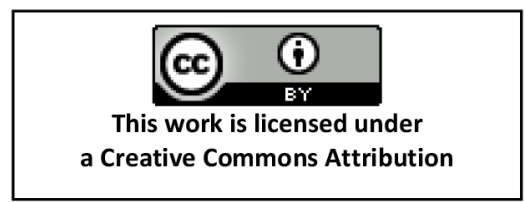

